\title{
April 96
}

\section{Av Bärbel Westphal}

Länk till presentation av Bärbel Westphal

\section{April 96}

Min morgons tidiga tröst är trastens mjukt klagande toner. Hackspettens manande hamrande till trots.

I min smak bearbetar han björken redan alltför energiskt.

Tystnaden går ännu runt husknuten. Gräsmattan sover bland krokusar. En värmevägg bildas på fönsterblecket.

Dra varligt undan gardinen en isig vårmorgon smyger sig på.

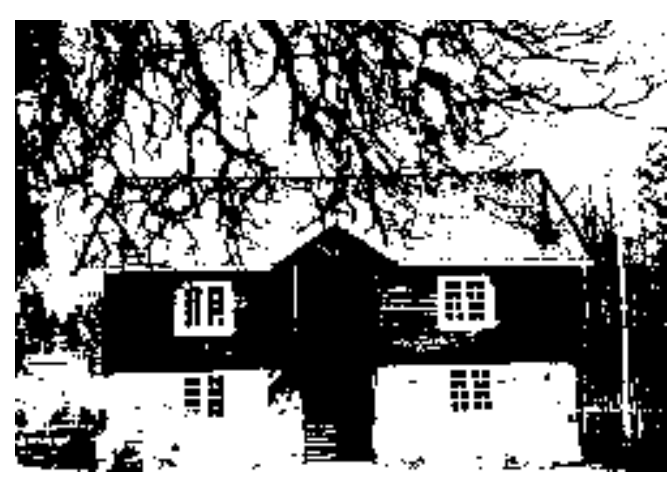

(C) text och foto Bärbel Westphal 